\title{
Portrayal Of Women In Nigerian News Magazine
}

\author{
Ojiakor Ifeoma Ph.D. \\ Department of Mass Communication, \\ Imo State University, Owerri \\ Nkwam-Uwaoma Adeline Ph.D. \\ Department of Mass Communication \\ Imo State University, Owerri \\ Victor Tubo \\ Department of Mass Communication, \\ Imo State University, Owerri \\ Okalla Fabian \\ Department of mass communication, \\ IMO State University OWerri
}

\begin{abstract}
News stories and items have contributed to the subjugation of one sex while increasing the visibility of the other. The way and manner gender is represented have been and will continue to be a subject of discursive struggle between pro-feminists and antifeminists. However, most studies seem to concentrate on newspapers and advertisements using pictures and images as units of analysis at the near exclusion of news magazines and news stories. This has necessitated having the beam light on news magazines and specifically on news stories. This study therefore examined Tell and The News magazine to ascertain the portrayal of women in the news and consequently formed research questions to test the invisibility and under representativeness of women in Nigeria news. Using content analysis of the sampled magazine from January 2014 to June 2014, the study found out amongst other things that women are underrepresented in the news as subject and reporters. Also, the work is linked to media framing theory which posits that the way the media selects some aspects of a perceived reality and makes them more salient in a communication text, promotes a particular problem definition, causal interpretation, moral evaluation, and/or treatment recommendation for the item described". The paper therefore recommends increased visibility of women in the media through training of communication teachers and incorporating gender course in schools and also doggedness when the going gets tough as expected.
\end{abstract}

\section{INTRODUCTION/BACKGROUND}

The 1995, 2000, 2005 and 2010 Global Media Monitoring Project (GMMP) studies have consistently revealed that women are grossly underrepresented in news coverage in contrast to men. The 2010 research confirmed an increase in women's presence in the news which nevertheless remains persistently slow. At present, only $24 \%$ of the people heard, read about or seen in the news are female. This is a rise from $21 \%$ in 2005 and $18 \%$ five years prior, in 2000. The studies equally showed a paucity of women's voices in news media content in contrast to men's perspectives, resulting in news that presents a male-centered view of the world (GMMP, 2010). 
A study of Australian media in November 2009 found that only $24 \%$ of people, who were heard, read about or seen in news stories were female. In sports stories, this figure fell to $1 \%$. Of the $24 \%$ of female in news stories, $44 \%$ were victims of crimes, accidents, war, health problems or discrimination, and only $32 \%$ of the stories presented or written by female reporters and news readers. (www.communities.wa.gov.au). Media affects our ideas of who we are and what we could be. This also translates to the generally accepted ways of being male or female. Gender stereotypes exist and are perpetuated by peer pressure, family upbringing, culture and tradition, politics, role models and media representation.

The mass media - television, internet, radio, newspapers, magazines and films - is part of our everyday life. It is a powerful tool that provides us with information and entertainment. It reflects our society and it influences the way we think. The demonstrated gender inequality in the media has significant consequences. We create our identity in relation to the images we see around us from a young age.

Findings from numerous studies like Ikem (1996); Abayomi (2000) and Oyinade et al (2013) have revealed that the media have direct impact on our lives, with the power to shape and mould our opinions on issues, people and events. Such impact appears to be hinged on stereotypes.

Stereotypes are representations and impressions of certain groups and aid in explanations according to McGarty, Yzerbyt, and Spears (2002) in Gizycki (2009). Symbols and stereotypes become a way for relaying specific messages and complex ideas, and these messages could be portrayed in a more simplistic fashion through the shorthand of stereotypes. For Gizycki (2009), female stereotypes are still prevalent as his theses found that $89 \%$ of all advertisements contained at least one stereotypical depiction. The production and consumption of reality could be stereotypic. News coverage, reporting and broadcasts have slants, which intentionally or unintentionally perpetuate stereotypes.

In a study conducted by Akinfeleye (1996) cited in Abayomi (2000), "there are 52 journalism (mass communication) training institutions offering various programmes from Diploma to $\mathrm{PhD}$ degree in mass communication in Nigeria; and the findings of his survey revealed that $52 \%$ of the students enrolled are female while $48 \%$ are male. However, despite the increasing enrolment of women in journalism and mass communication training, the ratio of men to women in journalism in Nigeria still remains predominantly patriarchal. Where do female journalists end up? Does their disappearance have anything to do with the invisibility of women according to the GMMP study?

Defenders of the portrayals of women in mass media argue that the nature of the imagery used is a direct response to what the consumers respond positively to. In other words, if for example light skinned women are over-represented in film, advertising or as news casters, it is because they appeal the most to the audience. Similarly if younger women appear most often on the screen, then it must be because the audience prefers to see them. At this juncture, is the invisibility of women what the society wants to see? Can the same society fighting for equal playing ground for both male and female turn around and sideline women when it comes to media representation or do the media producers give the audience what they think they need through agenda setting and media framing. Does that imply that there is a uniform reading of messages and probably uniform effects of same?

From studies on media effects, there has been a new paradigm shift from powerful effects to limited effects and to the constructed meaning of messages. The most recent being the 
construction age in which meaning is understood as constructed out of the historically and socially situated negotiation between institutional producers of meaning and audiences as producers of meaning. Texts are polysemic in nature which leaves room for some form of construction and negotiation. The construction of meaning is framed between its producers and audiences - based upon some form of negotiation. This also brings into play the activity of the receivers who are not as passive as powerful effects theory of the media made them appear to be. Things do not mean and do not have a fixed translation but are socially constructed.

According to Hall 1973 in Johannessen (2006), negotiation has become a key concept in mass media theory and research. The central element in the encoding/decoding model is that the construction of meaning takes place at the different moments in the mass communication process. The media text is located between its producers, who frame meaning in a certain way, and its audiences, who decode the meaning according to their rather different social situations and frames of interpretation. The basic mechanism is a continuous negotiation between media and audiences, empowering both sides.

Despite these arguments in literatures, this study wants to find out the visibility and dominance of women in Nigerian news magazine. This study seeks to determine if and how women are represented in the news magazine in relation to reportage, visibility, dominant images and placement; and also to determine if there has been a shift in stereotypical representation of women.

\section{STATEMENT OF THE PROBLEM}

News stories and items have contributed to the subjugation of one sex while increasing the visibility of the other. The way and manner gender is represented have been and will continue to be a subject of discursive struggle between pro-feminists and anti-feminists. However, most studies seem to concentrate on newspapers and advertisements using pictures and images as units of analysis at the near exclusion of news magazines and news stories. This has necessitated having the beam light on news magazines and specifically on news stories.

\section{OBJECTIVES OF THE STUDY}

Against the premise of the invisibility of women in the media and the presence of female in journalism schools and their dearth in the field, this study sought to:

$>$ Determine the number of stories on women in Nigerian news magazines

$>$ Ascertain the number of female news reporters in Nigerian news magazine

$>$ Determine different ways women are portrayed in Nigerian news magazine

$>$ Ascertain the placement of stories on women in Nigerian news magazines.

\section{RESEARCH QUESTIONS}

$>$ To what degree is female issues covered in Nigeria news magazine?

$>$ To what extent do female report news in Nigeria news magazine?

$>$ What different ways are women portrayed in news magazine?

$>$ To what degree is prominence given to news on women in Nigeria news magazine?

\section{SIGNIFICANCE OF THE STUDY}

This work is significant in terms of relevance in that media presentation and representation affects human relationship and the findings from this study and other related studies will help address gender inequality thereby promoting gender equality and subsequent achievement of the $3^{\text {rd }}$ MDG goal which is to promote gender equality and empower women. 
Findings from this study will corroborate the dominant impression of under visibility of women and will therefore assist media organization with data for reappraisal and reevaluation of gender issues with the objective of formulating gender sensitive operational policies.

It will also provide pro-feminists group with data to intensify their struggle and may persuade the anti-feminist group to relent in their opposition quest.

It will also add currency to existing literature on gender representation in the media.

\section{SCOPE OF THE STUDY}

This study will look at Tell and The News magazine from the period of January to June 2014. One of the characteristics of a magazine is the assortments of content ranging from news stories, advertorials, and photo news. The scope of this study will be limited to only news stories at the exclusion of advertisements and photo news.

\section{OPERATIONAL DEFINITION OF TERMS}

Portrayal: visibility of women in news magazine News magazine: Tell and The News magazine

Women: every female regardless of age

Dominance: majority in number of stories and number of bylines

\section{LITERATURE REVIEW}

Several researchers, namely Nixon (1997), Ukwueze (2008), Gizycki (2009), Abayomi (2000), Okunna (2002), Ojiakor (2010), Edema (2010) Oyinade et al (2013) and a host of others have examined the portrayal of gender and gender representation in the media with emphasis on advertising, films, photography and magazines. This section examines the current literature on portrayal and gender representation in the media. Also, the media framing theory will be used as an anchor point. The review is done under the following headings: gender, women in films, women in television advertisements, women in billboard advertisements, media portrayal of gender in photo news.

The word sex and gender are often interchangeably used by authors and researchers alike but the fact remains that they mean different things at different times. It is also our position that the use of either sex or gender is contextual. Be that as it may, while sex is the biological construction of being male or female, gender is a social construction as a result of sex which translates into masculinity and femininity.

Again, it has also been said that sex is fixed while gender is fluid. We want to state at this point that none is fixed but ever changing as scientific and medical evolution has allowed a male to change into a female thereby leading to the rather disturbing and confusing existence of transgender and even intersexual. From Wikipedia, intersexual or "Intersex" is a general term used for a variety of conditions in which a person is born with a reproductive or sexual anatomy that doesn't seem to fit the typical definitions of female or male. For example, a person might be born appearing to be female on the outside, but having mostly male-typical anatomy on the inside". It is also our assumption that intersex gave rise to transgender as a man who feels like a female inside will opt for a sex change so as to freely express his personality. Against this backdrop, what then is gender? 


\section{A BRIEF LOOK AT GENDER}

There abound different definitions of gender as there abound authors. The recent existence of transgendered people has heightened the contention of a universal definition of gender. Owing to that development, gender has become a highly contested word within the cultural, social and academic environment. An observation that prompted Van Zoonen to assert that, "the meaning of gender is never given but varies according to cultural and historical settings and is subject to ongoing discursive struggle and negotiations".

For Omenugha, gender is seen as cultural or social construction of sex, it is seen as not simply the sex one is (male or female) but rather a set of meanings that sex assume in a society. It spells out the dos and don'ts that go with both sexes. Permit me to say that gender is the yardstick that measures acceptable and unacceptable behaviors in a particular society.

In the same vein, Learning Seed (2009) saw the word gender as the social and cultural traits usually attributed to one sex or the other. For better or worse, society has different expectations, rules, and standards for men and women.

The definitions can go on and on saying the same thing in different ways. What it then means is that gender is better explained than an attempt to give a straight jacket definition. This may also have necessitated the concept of 'doing gender'. Explaining 'doing gender' is Learning Seed (2009) who explained that Gender doesn't mean physiological sex, but rather the social and cultural traits that society attributes to the sexes. Gender is flexible spectrum, and both men and women adopt traits that are traditionally considered masculine or feminine in different situations.

We understand the point made by learning seed as gender is not about the rightness or wrongness but the appropriateness. This is borrowing a leaf from Fletcher's situation ethics theory. By so doing, it is 'doing gender' at play. Yes, it involves knowing and applying the appropriate trait at the appropriate time regardless of sex.

Gender theorist Margaret Fuller in Learning Seed (2009) wrote: "Male and female represent the two sides of the great radical dualism. But in fact they are perpetually passing into one another. Fluid hardens to solid, solid rushes to fluid. There is no wholly masculine man, no purely feminine woman."

For this work, gender is the characteristics of masculinity and femininity evident in a given society. With most societies, accepted notion of gender often construct masculinity and femininity as opposites and is greatly influenced by the collective practices of institutions such as school, church, media and family, which construct and reinforce particular forms of masculinity and femininity. Indeed, Men and women are forced to live within the constraints where these ideological apparatus of gender puts them.

\section{MASCULINITY}

Masculinity is the socially constructed way of being male in a given society. Such qualities include but not restricted to self-reliance; strength; aggression; courage; respect; success, dominance. According to a study by Ojiakor (2010), she found out that such images abound in every sphere of the society so much so that they are also evident in billboard advertisement as advertisers are trying to draw from the repertoires of daily life.

It is this obsession of men with masculinity that led to patriarchy where men are afraid of losing in the wake of gender equality and which guarantees the dominant position of men and 
the subordination of women. If men and women are treated and seen as equal, who will the men lord over? A master needs a servant to become a master. What then is patriarchy? Bhasin (1993) sees patriarchy as a system of male domination and authority. PATRIARCHY is a social system in which males are the primary authority figures central to social organization, occupying roles of political leadership, moral authority, and control of property, and where fathers hold authority over women and children. It implies the institutions of male rule and privilege, and entails female subordination. Many patriarchal societies are also patrilineal, meaning that property and title are inherited by the male lineage. At this point, we want to state that coming to Nigeria, patriarchy is most evident within the Igbo-African society where civilization and modernization have not succeeded in shaking their stand on women and their subordinate position. Men can do and get away with anything unlike their female counterparts because of the cliché that it is a man's world and therefore for them, they are above statues, morality and law.

Worthy of note is that patriarchy evolved due to historical and cultural, rather than biological conditions as there are females who possess the masculine characteristics and more. At this juncture, let us also take a look at femininity.

\section{FEMININITY}

With the trend evident in masculinity, the word feminine carries an alluring picture perfect of what a woman should be. It is an encompassment of the social construction of a woman. It is social because it is not biological but an offshoot of the verbal and non verbal desires of the society to beat every female into being feminine so as to give room for the men to be masculine. From Wikipedia, Femininity is socially constructed, but made up of both sociallydefined and biologically-created factors. Indeed, the definition of femininity is the result of how females must behave in order to maintain a patriarchal social system. Femininity then becomes a set of attributes, behaviors, and roles generally associated with girls and women. Such traits include gentleness, empathy, sensitivity, domesticity and discreetness, love, beauty, caring, sweetness, compassion, tolerance, nurturance, deference, and succorance.

It is the traits of supposed femininity that have led to divisions among the women who experience womanhood differently from what society spells it out to be. Class, educational level, orientation and culture intervene in uniform experiences as a woman. Such contention led to Feminism which is a socio-political and philosophical position about the relationships between men, women and power. It is the same absence of a common ground that led to the different types of feminist groups which includes Liberal Feminism or second wave feminism, Radical Feminism; Ecofeminism; Marxist Feminism ;Socialist Feminism; Womanist; Lesbian Feminism; Separatist Feminism; Power Feminism; Revalorist Feminism; Third Wave Feminism amongst others.

\section{SYNOPSIS OF NEWS MAGAZINE}

Magazines constitute an important source of information in literate societies. Their importance lies in the current information they carry. This information keeps the readers informed of current events as well as serving to educate and entertain. The news magazines published in Nigeria are general interest titles intended for a mass audience, including both the general public and academics.

A news magazine is a typed, printed, and published piece of paper, magazine or a radio or television program, usually weekly, showing articles on current events. News magazines generally go more in-depth into stories than newspapers or television programs, trying to give the reader an understanding of the important events, rather than just the facts (Wikipedia). 
There is no consensus about the history of magazine in Nigeria but according to Okunna and Omenugha (2012), the modern magazine actually emerged in the last quarter of the nineteenth century.

A typical Nigerian news magazine is comprised of articles, stories, and features. This gives magazines an advantage over books which are designed to be read from cover to cover; a magazine can be read in its entirety or bit by bit. They also carry information in various subjects. Coverage includes humanistic subjects such as philosophy, psychology, music, language, commerce, business, sociology, and education. Nigerian news magazines are particularly rich in terms of the information they carry in the social sciences, and humanistic subjects (Afolabi, 1991, 36) in Olorunsola (1997).

\section{MEDIA AND GENDER}

The media is one of the central sites at which discursive negotiation over gender takes place (McQuail 2002). The media can be perceived as a major source of definitions and images of social reality. Thus, the media is also the place where the changing culture and values of societies and groups are constructed and most visibly expressed. What it means to be a male or female is formulated from the media which is seen as a mirror of reality. More so, the media is commonly seen as a potential means of influence, control, and innovation in society. As a result, few significant social issues are addressed without some consideration of the role of the mass media. "The media has a role to play in the struggle for gender transformation and in saluting the achievements of women in the society, in order to inspire others" (Tanzania Gender Networking Programme 1997) in Johannessen 2006. As a socializing agent, the media determines the kind of gender images and imposes the same on their audience be they negative or progressive. Children accessing the media will grow up adopting the conditionalized images and perpetuate them for better or for worse; adults may tend to regard the images as fixed, unchangeable and hand them down to the young generations through various cultural practices, (Chupa 1996) in Johannessen (2006).

Using 14 newspapers, over a two week period, television dramas in Swahili and combining with personal and focus group interview, Johannessen (2006) sought to investigate the role of the media in the Cultural Struggle of Gender Transformation in Tanzania and found out that the media is important especially for a woman movement, because we need to get issues discussed. What we need to do is initiate a dialogue so that the issues that are emerging in the woman movement can really be part of a national debate that can engage people into a dialogue where they see the rationality of the issues that we are talking about. The media is not the only tool for carrying out dialogical encounters, but it is the only arena that provides a potential shared public discourse. As such, the media plays a crucial role for the wider dissemination of ideas, issues and actions, and by redefining collective identities, which can ease the struggle for gender transformation. It is by participating in the intersection of a wide range of social discourses and practices that subjectivity is constructed and reconstructed. How then is the media being used to address gender inequality when it is through the same media that the oppression of women is more evident? This may have necessitated the purpose of the present study.

\section{INVISIBILITY OF WOMEN}

To measure the visibility of women, GMMP, On 10 November 2009, monitored 1,281 newspapers, television and radio stations in 108 countries for the fourth GMMP. The research covered 16,734 news items, 20,769 news personnel (announcers, presenters and reporters), and 35,543 total news subjects. The major findings were that only $24 \%$ of the people heard or read about in print, radio and television news are female. In contrast, $76 \%$ - more than 3 out of 
4 - of the people in the news are male. Also News continues to portray a world in which men outnumber women in almost all occupational categories, the highest disparity being in the professions. It was also found out that $13 \%$ of all stories focus specifically on women. As persons interviewed or heard in the news, women remain lodged in the 'ordinary' people categories, in contrast to men who continue to predominate in the 'expert' categories. Even though there appears to be an increase in the visibility of women from $17 \%$ in 1995 to $24 \%$ in 2010 , it can be concluded that women are still largely invisible. An interesting fact is that there seems to be an increase in visibility of women as television presenters which was put at 37\%. The reason for the increase as presenters may likely boil down to the issue of stereotypes while attractive looking women are used as reporters and anchor person and are replaced once they show any sign of aging. A comparative analysis of the findings from 1995-2010 reveals an overall glaring deficit in the news media globally, with half of the world's population barely present.

However, the finding will be more useful if the researchers will pick more days in a year to measure if a similar result will be obtained. Using a day to make conclusion may not be accurate as for instance, if the day of data collection were to be the day the school girls were abducted, women would have dominated the news which will be misleading. However, their result has been consistent with the finding of other research like Okunna (2002) which implies that their data collection period did not influence the findings and conclusions.

\section{IMBALANCE IN MEDIA RELATIONS}

From a study in 2002, Okunna came to the conclusion that Gender relations in Nigeria are characterized by lots of imbalance, to the disadvantage of women notwithstanding the level of consciousness and awareness even in the twenty first century. The larger society and the male subculture still see women and their aspirations as subordinate, resulting in a situation in which the marginalization, trivialization and stereotyping of women are glaring aspects of Nigerian life.

From content analyzing four news magazines and five national newspapers using the GMMP 2000 media monitoring format, The findings show that the packaging of news is still 'men's work' in Nigeria. Of the 101 reporters whose bylines appear in the 42 newsmagazine stories, $92(91 \%)$ were male while a very low $9 \%$ were female.

Furthermore, women were invisible as people in the news especially in newsmagazines. She found out that a disproportionate $86 \%$ of people in the news are male, while women accounted for a mere 14\%: 675 people appeared in the 42 new stories, 581 of them men. Women's invisibility in the news is also reflected in newspaper coverage. Only 93 (16\%) of the 566 news stories involve women, and only 53 of these have women as their central focus.

In addition to not being given prominence in terms of frequency of appearance, women are also denied prominence in being quoted and seen in photographs. A total of 61 photographs appear on the covers of the newsmagazines used in this study; a mere $10 \%$ or 6 photographs are of women. Similarly, out of the 263 photos which accompany the full news reports, only 30 (11\%) are photos of women. The situation is the same in newspapers where women are hardly quoted and their photographs are rarely used in news stories.

She therefore recommends social transformation of Nigeria and introduction of gender courses as a means of producing gender sensitive journalists. 


\section{WOMEN IN FILMS}

Considering the importance of improving the portrayal of women in the communication media which are powerful vehicle for moulding public opinion and determining public perception of social realty, Okunna (2002) sought to analyze 10 Igbo home videos for the following objectives: the portrayal of women in the films (positive or negative); the image of women (positive or negative), and the possible influence of this image on the respondents perception of women. The study was built on the premise the empowerment is needed where weakness and subjugation are apparent. For her, the decentralization or marginalization of women and their disadvantaged position are at the root of the global movement for the empowerment of women or 'the women agenda'. Also Using FGD, the study which was designed as a pilot study, found out that the roles and images of women were predominantly negative. On whether the images were realistic, 63\% were of the opinion that it was unrealistic. A twist in the findings is that even though majority sees the image as unrealistic, they unanimously agreed that the negative and unrealistic portrayal of women are capable of negatively influencing people's perception of women and behaviors towards them.

From the data, the researcher concluded that such films will only lead to the subjugation of women by increasing men's disdain for women; sow distrust between women; undermine women's confidence in themselves; and strengthen the forces which push women to the background in this patriarchal society.

Be that as it may, there was no background of the producers to ascertain what influenced their production. A similar study should look at the movies of two different producers and conduct a comparative study with a view of ascertaining if their personality influences their productions. This is because ones background to a great extent influences one's life philosophy.

\section{WOMEN IN TV COMMERCIALS}

Ukwueze (2008) studied the portrayal of women in 2 Nigerian commercials (AIT and NTA Awka). He found out that women often advertise domestic products like golden morn, Milo, butter etc far more than non-domestic products like cars, banking. He also observed that women are highly stereotyped in Nigerian TV commercials. A careful monitoring of the adverts showed women deriving satisfaction from the achievement or happiness of others, especially men and children. Conclusively, he wrote that in Nigeria, today, women are still largely stereotyped but the sexism rate is low, therefore one can say that there are more stereotyped commercials against women than there is of sexism and that there is limited portrayal of women as professional in comparison with men. Once again, this study like others concentrated on pictures, images and adverts while neglecting words.

\section{GENDER REPRESENTATION IN ADVERTS}

Similar to the study by Ukwueze is Ojiakor (2010) who analyzed male and female representation in billboards in Nigeria. Using semiotic and textual analysis to analyze 100 billboards, the study found out that men are located mostly outside the home while the females were often seen or located within the home. Also, the lack of connection between models and the advertised products was higher on the female side who mostly played decorative roles. Again, the study confirmed that the gender representation often seeks to replay the repertoires of daily life.

The study was on adverts and that is the difference with the present study which excludes adverts to focus on mainly news stories. 


\section{GENDER AND STEREOTYPES}

From a paper by Oyinade et al (2013), titled media, gender, and conflict: the problem of eradicating stereotyping of women in Nigeria, the authors built on the premise that the Nigeria media do not reflect the gender demographics of the nation and lays the bulk of the blame on stereotypes. There is a general consensus on the negative portrayal of women in Nigeria media. However, there is cross road as to the reason behind it.

While one school of thought blamed the lack of representation on Nigeria media, the "other argues that the misrepresentation of women is due to men dominating media echelon with no appreciation for women's role in the sustainable development of media (140). In view of the arguments by both camps, it is then the opinion of the researchers that stereotypes is to blame. For them, any history of gender and the media must recognize stereotypes; their existence had brought about significant consequences. One of such consequences is the creation of media images through the eyes of the male decision makers. Another is captured in the words of Short et al, (1995) that "when a group is construed negatively, it is easier to rally against such group. Such a label makes it psychologically easier to discriminate against the member of the group".

Supporting their line of argument is Omenugha (2001) in Oyinade (2013: 141) who indicts the Nigerian media on their politics of exclusion, noting that the Nigeria media is guilty of stereotyping and is caught in this web of discordant culture that continues to exclude women and thereby increases their vulnerability.

By way of conclusion, they concluded that in the 21st century, the need for change cannot be more apparent as the world can no longer sit idle and turn a deaf ear to gender inequality taking into account the role women had played and continued to play in ensuring peace and prosperity at home and abroad, economic prosperity in the work place, sustainable development across the board, and peace and harmony in the political front. As the world progresses Nigeria must take interest in promoting gender equality, encourage and facilitate social changes that are fundamental to the mobilization of gender equality and issue of concern to women.

\section{THEORETICAL FRAMEWORK}

This paper was anchored on the framing theory. Entman in Wimmer \& Dominick 2014) defined "framing as selecting some aspects of a perceived reality and making them more salient in a communication text, in such a way to promote a particular problem definition, causal interpretation, moral evaluation, and/or treatment recommendation for the item described". Framing theory has a lot of similarity with agenda setting theory in that the manner of presentation of issues in the media confers importance or insignificance on an issue, group or persons. From research, it can be said to be an off shoot of agenda setting as they are both concerned with how the media agenda is set, and how the media choose to portray the issues they cover or otherwise known as framing analysis. Framing analysis recognizes that media can impart a certain perspective, or "spin," to the events they cover and that this, in turn, might influence public attitudes on an issue.

Frames shape various levels of reality. The type of story notwithstanding, the concept of framing consistently offers a way to describe the power of a communicating text. For example, Iyengar and Simon (1993) found a framing effect in their study of news coverage of the Gulf War. Respondents, who relied the most on television news, where military developments were emphasized, expressed greater support for a military rather than a diplomatic solution to the crisis. In their study of the way media framed breast cancer coverage in the 1990s, Andsager 
and Powers (1999) discovered that women's magazines offered more personal stories and more comprehensive information, while news magazines focused more on the economic angle, stressing research funding and insurance.

Framing is divided into frame building; frame description and comparison; and framing effects. The type relevant to this study is frame description and comparison which researchers use to identify and describe how media frame general and specific issues. This study will therefore study how the media frame issues that concerns women with the rationale of establishing a trend or pattern.

\section{RESEARCH METHODOLOGY}

Under this section, the following issues are described: research methodology, research design, population of study, sampling, measureable variables and pilot study.

\section{METHODOLOGY}

Research is a systematic investigation, involving the analysis of information (data), to answer a question or contribute to our knowledge about an educational theory or practice. It relies on methods and principles that will produce credible and verifiable results" McMillan J \& Wergin J. (2010). Research methodology is procedures used in making systematic observation in order to obtain data, evidence or information as part of a research project or study. The method of data collection for this study was primary through content analysis. Kerlinger (2000) in Wimmer \& Dominick (2014) defined content analysis as a method of studying and analyzing communication in a systematic, objective, and quantitative manner for the purpose of measuring variables". It can also be seen as the systematic method of reading or studying the manifest content of communication over a time frame to see whether there is a pattern or trend.

The justification for the choice of content analysis for this study is that it is useful for assessing the image of a particular group in a society. For Wimmer \& Dominick (2014), ever growing number of content analyses have focused on exploring the median images of certain, minority or otherwise notable groups. The objective of content analysis was solely to make inferences about the media's responsiveness to demands for better coverage, or to document social change.

For this study, content analysis therefore becomes a veritable tool for analyzing the level of visibility of women in Nigeria news magazines.

\section{RESEARCH POPULATION}

The research population for this study is news magazines published in Nigeria and also has national spread. Owing to time constraints, it became imperative to select a sample. The population therefore was purposely narrowed down to "Tell" and "The News" magazine. Special editions were excluded. Also excluded are photo news and advertorials, mailbox and milestones. The period under study was January 2014 to June 2014. Both magazines are a weekly magazine which means there are 4 issues in a month. The total number of issues therefore becomes $4 \times 6=24$ for both magazines; it will be 48 which can be considered large.

To reduce the sample size, the researcher purposely chose the $1^{\text {st }}$ and $3^{\text {rd }}$ week of every month for Tell magazine and the $2^{\text {nd }}$ and $4^{\text {th }}$ week for The News magazine. The justification is to ensure representativeness as every story within the month is captured in the weekly reportage. With this, the sample size becomes 24 which can be manageable within the timeframe for the completion of the study. 


\section{Unit of Analysis}

The units of analysis were news stories while the content categories were the main subject of story, byline of the story, placement or dominance of women issues in the magazines and the different ways women are portrayed in the news magazines.

\section{Data analysis}

The data was analyzed using textual analysis and presented in tables using simple percentage.

\section{DISCUSSION OF FINDINGS}

To determine the number of stories on women and to answer the first research question on the degree of female issues covered in Nigeria news magazine, it was found out that from Tell magazine, there was a total of 179 stories while 'The News' carried a total of 186 news stories. In other to answer the question on the number of stories on women, the stories were split into stories that focused on only women and men. The data revealed that out of the 179 stories in Tell, $24.02 \%$ or 43 news stories focused only on women while a whopping $66.48 \%$ (119) was on males while $9.49 \%$ focused on both male and female.

From the news section, it can also be seen that a similar trend was evident as out of a total of 186 stories, $19.35 \%$ (36) had females as its subject while $66.12 \%(123)$ was on males and the remaining $14.51 \%$ (27) had both male and female stories.

A combined data from both magazines also saw stories on women put at $21.64 \%$ while those on men were at $66.30 \%$. Therefore, the answer to the above question is that women are largely underrepresented as the data has revealed. In other words, the media pay inadequate attention to issues that are particularly significant to women. This finding is consistent with the GMMP (2010) findings that only $24 \%$ of the people heard or read about in print, radio and television news are female. In contrast, $76 \%$ - more than 3 out of 4 - of the people in the news are male. A similar trend was evident in the study by Okunna (2002) where it was found out that in newsmagazines, a disproportionate $86 \%$ of people in the news are male, while women accounted for a mere $14 \%$.

An observation from this study is that even though women were largely invisible when compared to men, their presence at all in the media was largely due to the kidnapping of the chibok girls by boko haram which attracted global attention and then had the beam light on women. That notwithstanding, there were more political stories that focused primarily on male subjects at the near neglect of female subjects. Suffice it to say that without the chibok incidence, the percentage would have been lower than it presently was.

If a comparative analysis is to be made between the two magazines, not much can be said to be the difference as they both appear to have a similar policy with regards to gender representation as their female representation is $24.02 \%$ and $19.35 \%$ respectively even though it can be said that Tell recorded a higher percentage of stories on female subjects.

From the study of Ashong A \& Batta H (2011), a disproportionate 86 percent of people in the news were male while women accounted for a mere 14 percent.

An explanation for the similarity in representation of women may be attributed to the observation of Oyinade et al (2013) that that the Nigeria media do not reflect the gender demographics of the nation and lays the bulk of the blame on stereotypes while another school of thought lays the blame on lack of representation in Nigeria media as the misrepresentation of women is due to men dominating media echelon with no appreciation for women's role in 
the sustainable development of media. Blaming stereotypes for invisibility of women is Omenugha (2001) in Oyinade (2013) who indicts the Nigerian media on their politics of exclusion, noting that the Nigeria media is guilty of stereotyping and is caught in this web of discordant culture that continues to exclude women and thereby increases their vulnerability.

For Sharma (N/A), the media is a carrier of information, ideas, thoughts and opinions. It is a powerful force in influencing people's perceptions on a variety of issues and the way subjects dealing with women are treated indicated to a great extent the prevailing attitude of the society towards women.

The underrepresentation of women in 'Tell' and 'The News' magazines can be attributed to the framing theory whereby the issues concerning women are framed in a way to subjugate women instead of giving them a voice. For miller (2005), all groups do have a voice by way of their portrayal, but that voice or portrayal is not always correct and often distorted or even underrepresented.

From the content analysis, the magazines were divided into section and it was found out that majority of the stories on were under health and crime and violence section. Specifically, $3 / 4$ of the stories were on crime and violence and mostly revolved around the chibok kidnapping of the over 200 school girls and its aftermath. The women in the stories were then captured either protesting, rioting or as victim of the boko haram onslaught. More about the portrayal will be addressed by subsequent research questions.

To ascertain the extent females report news in news magazines, the bylines were considered. From Tell magazine, out of 179 stories, males bylines were 105 (58.65\%) while female bylines were less than half of the male bylines or 51 (28.49\%). There were bylines that cannot be straight jacketed into male or female and it was put under unisex section. The unisex section means that the names could either be a feminine or masculine name and to aid objectivity and eliminate bias as much as possible, they were confined to unisex section. From table 2, the unisex byline was $8(4.46 \%)$ and the stories that had no byline were $15(8.37 \%)$.

Coming to 'The News' magazine, female bylines out of 186 stories was $27(14.51 \%)$, the males had 135 (72.58\%), unisex was 13 (6.98\%) while no bylines was 11(5.91\%).

Cumulatively, out of 365 stories, female bylines were 78 (21.36\%) while the male byline was $240(65.75 \%)$.

The discussion of this data can only reveal one thing, that there is a dearth of female reporters in the field. This may also buttress the invisibility of women in the news as the men occupy the media echelon and thereby assign beats to sustain the status quo. According to GMMP (2010) report, the percentage of reporters in African newspaper, radio and television was 24\%, 38\% and $36 \%$ respectively. Also, from a study of Australian media in November 2009, only $32 \%$ of the stories presented or written by female reporters and news readers" (www.communities.wa.gov.au).

Further still, Okunna (2002) asserts that news packaging in Nigeria is still largely men's work as out of the 101 reporters whose bylines appear in the 42 newsmagazine stories, 92 (91\%) were male while a very low $9 \%$ were female. 
A similar finding was evident in the study by Ashong \& Batah (2011) that "of the 101 reporters whose by-lines appeared in 42 news magazine stories, 91 percent were male while nine percent were female.

Where are the women? This question comes up because previous research (Ashong \& Batta (2011; Akinfeleye (1996); Abayomi (2000) have shown that there are more females in journalism schools and more men in the field. An attempt at a justification for the near exclusion of women in the media was made by Ashong \& Batah (2011) who opined that "Media professionals who deal with important issues and political events are overwhelmingly men. Though increasing number of women work in media organizations, they are mostly production and continuity assistants while those who take broad decisions as proprietors, editors, directors, and managers are men".

In schools, journalism is seen as a female profession as a glance at the department of mass communication will reveal. However, when it comes to practice, journalism now becomes a male dominated field. What could be the explanation? An explanation could lie in stereotypes. Yes it is stereotypes that can convince women that field work is too masculine and stressful for a woman and so they divert to less stressful professions. Using a personal experience, when one of the researchers as a female was posted to government house as a correspondent, her colleagues doubted her ability to cope with the stressful riguor associated with being a state house correspondent. The complaints and murmur even got to the relevant authority and she was eventually reassigned even when she didn't want to. The researcher was denied the opportunity to practice her chosen profession on the basis of her sex. This may have also been the experience of other female journalism students so much so that they opted for a safer occupation.

The above example is one of the negative effects of stereotypes as it is limiting. It clips the wings of the disadvantaged group which is heightened by the societal attachment of family care to females. Indeed, caring for the family have also become a limitation as the males in the field will always stress that journalism is not for married women as it often puts reporters in uncomfortable positions like staying late nights and even going to mundane places all in the name of following a lead. I want to ask if those men that practice journalism are not or never married or are they married to spirits. Why does marriage have to come $n$ the way of career progression of women and excludes or immunes the men? Then again, the partial treatment of gender has thrived as a result of stereotype which is perpetuated by the media amongst other ideological apparatus of gender.

Furthermore, in an attempt to ascertain the different ways women are portrayed in the two select news magazines, , the data collected reveals that the cumulative frequency of women's portrayal sees majority of the female subjects as victim. Victims has $31(39.24 \%)$ followed by subject with $18(22.78 \%)$. By subject is meant that the story revolved around a woman. The third in line is expert or commentator which has a frequency of $13(16.45 \%)$ and spokesperson at $9(11.39 \%)$.

A point worthy of note is that this study is focused on women and therefore sidelined the portrayal of men in the news stories. As was pointed out earlier; women were mostly in the news as a result of the security situation in the country which portrayed women as victim of the boko haram attack especially with respect to the abduction of the school girls who are still missing till date. 
It is therefore not surprising that the predominant portrayal was as victims. It is also not surprising that portrayal as subject came second considering that being subjects is also linked to the abduction incident as there were protest to bring back our girls and that came under the 'subject' section.

In the expert section saw the likes of Okonjo Iweala, Dame Patience Jonathan, Oby Ezekwesil and Allison Madueke making the news as sources. The trio of Patience, Okonjo and Madueke were also in the news as the women who rule Jonathan while Jonathan rules Nigeria. The report saw women as manipulative as they were misdirecting and distracting Jonathan from important issues of national interest.

For Oby Ezekwesil, she was captured championing a 'bring back our girls' protest in Abuja and since the girls were abducted from their school and as a former education minister, she can be considered an expert when it comes to education and young girls' issue.

The findings of this study did not corroborate the findings of Ashong \& Batah (2011) that Women are portrayed in print and in broadcasting as self-deprecating and dependent, irrational, superstitious, and over-emotional. None of the themes identified by Ashong was present. It does not mean that their finding was wrong or that the finding of the present study is inaccurate but then again, it has a lot to do with the nature of story at the point of data collection. Since most of the stories on women were on crime and violence against them, it is not out of place for women to be portrayed as victims.

However, the findings of this research corroborates the findings of a study of Australian media in November 2009 where it was documented that of the $24 \%$ of female in news stories, $44 \%$ were victims of crimes, accidents, war, health problems or discrimination. (www.communities.wa.gov.au).

Here again and by implication, the way and manner of portrayal led to the conclusion that women are seen as victims and the conclusion comes from the framing of the issues. One can then also relate the portrayal to framing theory which according to Entman in Wimmer \& Dominick 2014) is defined "framing as selecting some aspects of a perceived reality and making them more salient in a communication text, in such a way to promote a particular problem definition, causal interpretation, moral evaluation, and/or treatment recommendation for the item described".

On placement of stories, prominence here is not in the number of stories on women but in their placement. For both magazines under study, there was a uniform pagination as both were 54 paged news magazines. The pagination was then divided into three and the total is 18 pages for front, middle and back. This means that for front pages is pages 1-18; middles pages is from 19-36 and the back pages are from 37-54.

Having operationalized placement and from both magazines, 23 (29.11\%) of the stories appeared on the front pages and 28 (35.44\%) at middle and back pages respectively.

Specifically, Tell had 11 front page stories on women out of $65 ; 19$ middle page out of 69 and 13 back page stories out of 45 . From tell, their front page is dedicated to health extra which is anchored by a female reporter by the name Janet Jackson. The news dedicated 12 front page stories to women out of 51; 9 to middles pages out of 62 and 15 pages to back pages out of 73 . 
On the whole, more of male stories dominated the front pages but that should be expected as male stories dominated the magazines which by implication mean that they will also dominate in their placement. A lot of importance is usually accorded to cover and front page stories. Suffice it to say that all the cover stories were displayed within the front pages and ran into the middle pages. Also, there was no cover story on a female subject. How can a female make the news when the decision makers of who should appear on the cover page are men? Also, with the 2015 election around the corner, politicking had increased and a subtle way of playing politics is through placement of politician in the news which led to a situation where interested candidates like Jonathan, Buhari, Fayemi and others made front cover stories.

Does it mean there are no female politicians in the country to grace or adorn the cover pages? With regards to female reported stories and their placement, it can be concluded from the content analysis that their stories ran throughout the whole pages with the exception of the health extra column that was repeatedly featured on the very front pages of Tell.

It is my position that if it were to be entertainment magazine, more women would have been on the cover and their function on the cover would have been primarily decorative. A fleeting glance at newspaper stand across the country will reveal this fact.

Summarily, more men adorn the cover pages while stories on women is spread across the magazine but more on middle and back pages and less on front pages.

\section{CONCLUSION}

It is no longer news that women are largely invisible in the media as a meticulous analysis of 2 Nigeria news magazine have revealed they had fewer stories than those of men and also male byline are greater in number than female bylines. What should be news is the way to address this anomaly.

In other words, this study affirms the report of GMMP 2010 and Okunna 2002 findings. The invisibility is both on paper and outside the paper as there were fewer female bylines than men. This invisibility also to a great extent is determined and reinforced by the way media treat or handle issues that bother solely on women with regards to level, extent and placement of coverage.

\section{RECOMMENDATIONS}

This study couldn't agree more with the recommendation of Okunna that there is an urgent need to improve the representation of women in the media by increasing their visibility as journalists and people in the news, as well as by eliminating sexism in media content even though the problem is more deep-rooted than this. The study therefore adopt recommendation of Okunna that the solution to the problem of gender and communication in Nigeria lies with adopting more 'radical' strategies in addition to the provision of quantitative data to show women's unequal representation in the media.

There should be a campaign against eradication of stereotypes which accounts for fewer female journalists in the field. Such campaign should incorporate the recommendation of Ashong \& Batta (2011) who proposed that Institutions involved in the training of communication practitioners should within the framework of gender mainstreaming adopt and implement policies aimed at addressing the imbalance in the enrolment of students into communication studies. In the same vein, strident attempt should be made through policy engineering to correct the lopsidedness in the engagement of communication teachers. 
I also support the adoption of alternative media proposed by feminists' researchers whereby women will own media houses and the factors of production so that they will be in a better position to cover and report on issues that bother on women objectively and not as the society will want it to be.

Finally, we recommend patience and endurance as balanced gender reporting and representation is not hanger pangs that can fade after a meal. It has and will always be a struggle that will pay off eventually if the right parameters, patience and endurance are in place.

\section{LIMITATION OF STUDY}

The major limitation of this study lies in the sample size as owing to time constraints, only two magazines was analyzed which may not be representative. Another limitation was in the sampling which was not a census even when the period under was six months. Further study should conduct a census and also expand the period of study over a year. There is also need to contain photo news so as to have a more comprehensive picture of gender portrayal in news magazines.

\section{References}

Ashong A \& Batta H (2011) Gender Representation in Communication Education and Practice in Nigeria. J Communication, 2(1): 13-22 (2011).

Bhasin, S (1993) what is patriarchy? New Delhi: Raj Press

Edema, P (2010) Media Portrayal of Men And Women In Photo News: A Study Of Vanguard And The Guardian Newspapers. M.sc thesis: Nnamdi Azikiwe University, Awka.

Fairclough, N (1995) Media Discourse. London: Arnold

Gizycki, G (2009) "Female stereotypes in 21st century news and business magazines" (2009). Master's Thesis. Paper 3642.

Hall, S (1997) Representation: Cultural Representation and signifying practices. London: Sage Publications.

Jill Johannessen (2006) Gender, Media and Development. The Role of the Media in the Cultural Struggle of Gender Transformation in Tanzania. Norwegian University of Science and Technology.

Learning seed (2009) Gender and communication. Gender_and_communication_guide.pdf

Miller, K (e.d.)(2005) Communication theories: perspectives, processes, and contexts (2 ${ }^{\text {nd }}$ ed). New York: McGrawHill Companies, Inc

Mulesa, L (2012) The Role of Media in Communicating Messages On Gender: A Case Study of Zanis. The University Of Zambia: M.Sc thesis.

Neuman, R \& Guggenheim, L (2011) The Evolution of Media Effects Theory: A Six-Stage Model of Cumulative Research. Communication Theory 21 (2011) 169-196. International Communication Association

Ojiakor I (2010) Gender Representation in Billboard Advertisements. Unizik: M.Sc thesis.

Okunna C \& Omenugha, K (2012) intro to mass communication. Enugu: New Generation Books

Okunna C (1996). “Portrayal of Women in Nigerian Home Video Films: Empowerment or Subjugation?” Africa Media Review Vol. 10, No. 3.

Okunna C (2002) Gender and Communication in Nigeria: Is This The Twenty-first Century? Department of mass communication, Unizik Awka available at

http://www.portalcomunicacion.com/bcn2002/n_eng/programme/prog_ind/papers/o/pdf/o005se04_okunn.pd $\underline{\mathrm{f} 5 / 8 / 14}$

Olorunsola, R (1997) Nigerian news magazines and their importance: A review of recent literature. Volume 7 , number 2 spring 1997ISSN 1092-7441)

Oyinade, B, Ifedayo, Lamidi, I (2013) media, gender, and conflict: the problem of eradicating stereotyping of women in Nigeria. Kuwait Chapter of Arabian Journal of Business and Management Review Vol. 3, No.2; Oct. 2013 
Ifeoma, O., Adeline, N. U., Tubo, V., \& Fabian, O. (2018). Portrayal Of Women In Nigerian News Magazine. Advances in Social Sciences Research Journal, 5(4) 305-322.

Roger D. Wimmer and Joseph R. Dominick (2009) Research in Media effects (Revised October 2009) Mass Media Research: An Introduction, $9^{\text {th }}$ Edition

Roger D. Wimmer and Joseph R. Dominick (2014) mass media research (10 ${ }^{\text {th }}$ edition) Wadsworth Cengage Learning.

Sharma A (NA) Portrayal of Women in Mass Media. Media watch ISSN 2249-8818

http://cdn.agilitycms.com/who-makes-the-news/Imported/images/reports_2010/highlights/highlights_en.pdf $7 / 7 / 14$

http://en.wikipedia.org/wiki/Femininity http://en.wikipedia.org/wiki/Masculinity

http://en.wikipedia.org/wiki/Exploitation_of_women_in_mass_media\#Criticisms_of_the_media 